\title{
Astrocytes Protect Neurons from Hydrogen Peroxide Toxicity
}

\author{
Solange Desagher, Jacques Glowinski, and Joël Premont \\ Chaire de Neuropharmacologie, Institut National de la Santé et de la Recherche Médicale U114, Collège de France, \\ 75231 Paris Cedex 05, France
}

Recent reports indicate that neurons are particularly sensitive to hydrogen peroxide $\left(\mathrm{H}_{2} \mathrm{O}_{2}\right)$. The present study was undertaken to investigate the putative role of astrocytes in the modulation of the neurotoxic effect of $\mathrm{H}_{2} \mathrm{O}_{2}$. The exposure to $\mathrm{H}_{2} \mathrm{O}_{2}$ of cultured striatal neurons from mouse embryos induced a concentration-dependent $(10-1000 \mu \mathrm{M})$ cell death as estimated $24 \mathrm{hr}$ later. Two methods were used to estimate neuronal survival: the 3-[4,5-dimethylthiazol-2-yl]-2,5-diphenyltetrazolium bromide assay or an enzyme-linked immunosorbent assay with antibodies directed against an antigen located in neurons (microtubule-associated protein-2). The neurotoxic effect of $\mathrm{H}_{2} \mathrm{O}_{2}$ on neurons cocultured with astrocytes was strongly attenuated compared with that observed on a pure population of neurons seeded at the same density. Moreover, the protective effect of astrocytes depended on the astrocytes/ neurons ratio, a significant neuroprotection being detectable for 1 astrocyte to 20 neurons. Catalase seems to be the main hydrogen peroxidase activity involved in the neuroprotective effect of astrocytes. Indeed, in the culture conditions used, this enzymatic activity was enriched in this cell type compared with neurons; its inhibition, and not that of glutathione peroxidase, reduced the disappearance rate of the oxidant. On the contrary, glutathione peroxidase appeared to be the main enzymatic activity involved in the neuronal defense against $\mathrm{H}_{2} \mathrm{O}_{2}$ toxicity. Therefore, astrocytes could delay neuronal death in pathological situations in which $\mathrm{H}_{2} \mathrm{O}_{2}$ has been, at least partially, demonstrated to be involved.

Key words: astrocytes; hydrogen peroxide; neuroprotection; neurotoxicity; catalase; glutathione peroxidase
Oxidative stress is believed to be implicated in a wide variety of human degenerative disorders of the CNS, including Alzheimer's disease, Parkinson's disease, and amyotrophic lateral sclerosis, and in pathological conditions such as ischemia (Halliwell, 1992; Coyle and Puttfarcken, 1993; Olanow, 1993). The particular vulnerability of the brain to such damage could be related to its high rate of oxygen consumption. The cytotoxic oxygen species are mainly hydrogen peroxide $\left(\mathrm{H}_{2} \mathrm{O}_{2}\right)$ and two free radicals: superoxide anions $\left(\mathrm{O}_{2}{ }^{\top}\right)$ and hydroxyl radicals $(\mathrm{OH})$. However, the respective neurotoxic efficiencies of each of these oxygen species, as well as their respective roles in various experimental models of neurotoxicity, are debatable. Indeed, their rates of production are strictly interdependent because $\mathrm{O}_{2}{ }^{-}$spontaneously dismutates into $\mathrm{H}_{2} \mathrm{O}_{2}$, a reaction that is accelerated by superoxide dismutase. In addition, by reacting with iron or copper, $\mathrm{H}_{2} \mathrm{O}_{2}$ can lead to the production of OH: (Fenton, 1894; Haber and Weiss, 1934). As proposed by some authors, superoxide anions could be involved in the NMDA-induced neurotoxicity (Lafon-Cazal et al., 1993) but the respective contributions of $\mathrm{H}_{2} \mathrm{O}_{2}$ and $\mathrm{OH}$ in this process remain to be determined. The $\beta$-amyloid protein that accumulates in CNS plaques during Alzheimer's disease (Glenner, 1988) is toxic for cultured cortical neurons (Loo et al., 1993; Behl et al., 1994) and, as recently proposed, $\mathrm{H}_{2} \mathrm{O}_{2}$ could be responsible for this neurodegenerative process (Behl et al., 1994). A neurotoxic

\footnotetext{
Received July 31, 1995; revised Jan. 19, 1996; accepted Jan. 24, 1996.

This study was supported by Institut National de la Santé et de la Recherche Médicale and grants from Direction des Recherches, Etudes et Techniques (No. 94158) and Rhône-Poulenc-Rorer.

Correspondence should be addressed to Solange Desagher, Chaire de Neuropharmacologie, Institut National de la Santé et de la Recherche Médicale U114, Collège de France, 11 Place Marcelin Berthelot, 75231 Paris Cedex 05, France.

Copyright $(\mathcal{C} 1996$ Society for Neuroscience 0270-6474/96/162553-10\$05.00/0
}

effect of $\mathrm{H}_{2} \mathrm{O}_{2}$ originating from microglial cells has also been reported (Théry et al., 1991).

As generally accepted, the enzymes catalase $\left(\mathrm{H}_{2} \mathrm{O}_{2}\right.$ oxidoreductase: FC. 1.11.1.6) and glutathione peroxidase $\left(\mathrm{H}_{2} \mathrm{O}_{2}\right.$ glutathione oxidoreductase: EC 1.11.1.9) participate in the cellular defense against $\mathrm{H}_{2} \mathrm{O}_{2}$ (Buckman et al., 1993; Makar et al., 1994; Makino et al., 1994). However, little is known about the cellular distribution (i.e., neurons vs astrocytes) of these enzymatic activities and, therefore, about the putative role of astrocytes in the modulation of the neurotoxic effect of $\mathrm{H}_{2} \mathrm{O}_{2}$. In the present study using cultured cells from the striatum of mouse embryos, we demonstrate that astrocytes protect neurons against $\mathrm{H}_{2} \mathrm{O}_{2}$ toxicity.

\section{MATERIALS AND METHODS}

\section{Materials}

Swiss mice were obtained from IFF $\Lambda$ Credo (Lyon, France); PBS without calcium and magnesium, trypsin-EDTA solution, and culture media from Gibco (Gaithersburg, MD); fetal calf serum from Dutcher (Brumath, France); NU-Serum from Becton Dickinson (Bedford, MA); mouse monoclonal anti-microtubule-associated protein 2 (MAP-2) antibodies from Biomakor (Rehovot, Israel); peroxidase-coupled goat-anti-mouse $\operatorname{IgG}$ from Biosys (Compiègne, France); monoclonal anti-mouse macrophage antibody (anti-MAC 1) from Serotec (Oxford, UK); antisera directed against glial fibrillary acidic protein (GFAP) from ICN Biochemicals (Costa Mesa, CA); phenylmethyl-sulfonylfluoride from Boehringer Mannheim (Mannheim, Germany); 6,7-dinitroquinoxaline-2,3dione (DNQX) from Tocris Cookson (Bristol, UK); D-2-amino-5phosphonovaleric acid (APV) from Research Biochemicals (Natick, MA). Horseradish peroxidase, catalase (bovine liver), superoxide dismutase (bovine erythrocyte), glutathione reductase (spinach), glutathione peroxidase (bovine erythrocyte), and all other chemicals or reagents used in the present study were purchased from Sigma (Saint Quentin Fallavier, France).

\section{Cell cultures}

Primary cultures of striatal neurons. Primary neuronal cultures were prepared using the method of El Etr et al. (1989) with slight modifications. 
Briefly, striata were removed from 14- to 15-d-old Swiss mouse embryos and mechanically dissociated with a flame-narrowed Pasteur pipette in PBS supplemented with glucose $(33 \mathrm{~mm})$. Cells were plated on 24-well NUNC culture dishes $\left(4 \times 10^{5}\right.$ cclls per well containing $0.5 \mathrm{ml}$ of medium; Roskilde, Denmark) previously and successively coated with poly-Lornithine $\left(15 \mu \mathrm{g} / \mathrm{ml}, M_{\mathrm{R}} 40 \mathrm{kDa}\right)$ and the culture medium containing $10 \%$ fetal calt serum. After the removal of the last coating solution, cells were seeded in a serum-free medium consisting of a 1:1 mixture of DMEM and Ham's F12 nutrient, supplemented with glucose (33 mM), glutamine (2 mM), $\mathrm{NaHCO}_{3}(13 \mathrm{~mm})$, HEPES buffer (5 mM, pH 7.4), penicillinstreptomycin ( $5 \mathrm{IU} / \mathrm{ml}$ and $5 \mu \mathrm{g} / \mathrm{ml}$, respectively) and a mixture of salt and hormones containing insulin $(25 \mu \mathrm{g} / \mathrm{ml})$, transferrin $(100 \mu \mathrm{g} / \mathrm{ml})$, progesterone $(20 \mathrm{nM})$, putrescine $(60 \mu \mathrm{M})$, and sodium selenite $\left(\mathrm{Na}_{2} \mathrm{SeO}_{3} ; 30\right.$ nM). Cells were cultured at $37^{\circ} \mathrm{C}$ in a humidified atmosphere of $92 \%$ air and $8 \% \mathrm{CO}_{2}$. After 6-7 d under these conditions, cells were immunocytochemically defined according to El Etr et al. (1989) as purified neurons devoid of detectable glial elements.

Primary cultures of striatal astrocytes. Primary cultures of striatal astrocytes were prepared as described previously (El Etr et al., 1989). Dissociated cells from striata were plated on $100 \mathrm{~mm}$ NUNC petri dishes $(6 \times$ $10^{6}$ cells per dish) previously coated with poly-L-ornithine $(1.5 \mu \mathrm{g} / \mathrm{ml})$ The culture medium consisted of a 1:1 mixture of Minimal Essential Mcdium (MEM) and Ham's F12 nutrient, supplemented with glucose (33 $\mathrm{mm})$, glutamine $(2 \mathrm{~mm}), \mathrm{NaHCO}_{3}(13 \mathrm{~mm})$, HEPES buffer $(5 \mathrm{~mm}, \mathrm{pH}$ 7.4), and $10 \%$ NU-Serum. After $7 \mathrm{~d}$ in vitro, the culture medium was changed, and cytosine arabinoside $(5 \mu \mathrm{M})$ was added for $48 \mathrm{hr}$ to prevent the formation of cell multilayers and the proliferation of microglial cells Thereafter, the culture medium was changed every $3 \mathrm{~d}$. Under these conditions, after $21 \mathrm{~d}$ in vitro, $>95 \%$ of the cells were immunostained against GFAP. Remaining cells $(5 \%)$ could be immature glioblasts or O2A progenitors, which are known to be unlabeled by GFAP antihodies (Eng, 1985). The astrocytic cultures were devoid of microglial cells because no staining was observed using anti-MAC 1.

Astrocytoneuronal cocultures and secondary cultures of striatal astrocytes. After 19-21 d in culture, astrocytes were washed in PBS and incubated in a trypsin-EDTA $(0.05$ and $0.02 \%$, respectively) solution for $5 \mathrm{~min}$ at $37^{\circ} \mathrm{C}$. Dissociated cells were harvested, and trypsin was saturated with $20 \%$ fetal calf serum. Astrocytes were washed, resuspended in the culture medium, and then seeded onto 5-d-old cultured neurons or into sister wells without neurons. For these secondary astrocytic cultures, the culture medium consisted of a 1:1 mixture of DMEM and Ham's F12 nutrient. The astrocytoneuronal cocultures, as well as the secondary astrocytic cultures, were cultured for an additional $24 \mathrm{hr}$ period.

\section{Neurotoxicity experiments}

Cells were first washed with Krebs' bicarbonate buffer (in mM): $124 \mathrm{NaCl}$, $3.5 \mathrm{KCl}, 1.25 \mathrm{~K}_{2} \mathrm{HPO}_{4}, 26.3 \mathrm{NaHCO}_{3}, 1.2 \mathrm{CaCl}_{2}, 1.2 \mathrm{MgSO}_{4} 10 \mathrm{HEPES}$, 11 glucose, previously equilibrated with $95 \% \mathrm{O}_{2} / 5 \% \mathrm{CO}_{2}$ at $37^{\circ} \mathrm{C}, \mathrm{pH} 7.4$, and preincubated for indicated times in the presence of different agents. Cells were then incubated in the same buffer at $37^{\circ} \mathrm{C}$ in a humidified atmosphere $\left(92 \%\right.$ air and $8 \% \mathrm{CO}_{2}$ for $30 \mathrm{~min}$, except when otherwise stated) in the presence of drugs. After the incubation period, cells were washed with Krebs' bicarbonate buffer and cultured for $24 \mathrm{hr}$ in the initial culture medium previously stored.

To obtain conditioned media, neurons or astrocyles were washed and incubated for different times with either $\mathrm{H}_{2} \mathrm{O}_{2}$ at the indicated concentrations or the control buffer. These incubation media were then collected and added for $30 \mathrm{~min}$ onto other washed neuronal cultures. The viability of the second cell cultures was assessed $24 \mathrm{hr}$ later, two methods being used for the quantification of the surviving neurons.

\section{MTT colorimetric assay}

This method is based on the reduction of the tetrazolium salt MTT (3-[4,5-dimethylthiazol-2-yl]-2,5-diphenyltetrazoliumbromide) into a blue formazan product mainly by the mitochondrial enzyme succinatedehydrogenase (Denizot and Lang, 1986). Therefore, the amount of formazan produced is proportional to the number of living cells. Briefly, the culture medium was replaced by a solution of M'l' $(0.5 \mathrm{mg} / \mathrm{ml})$ in PBS supplemented with glucose ( $33 \mathrm{~mm}$ ). After a $3 \mathrm{hr}$ incubation at $37^{\circ} \mathrm{C}$, this solution was removed and the produced blue formazan was solubilized in $1 \mathrm{ml}$ of pure dimethyl sulfoxide. The optical density of the formed blue formazan was estimated at $560 \mathrm{~nm}$.

\section{Enzyme-linked immunosorbent assay of MAP-2}

MAP-2 is a protein selectively localized in neuronal soma and dendrites (Matus et al., 1981). Therefore, its immunoenzymatic determination allows the distinction of neurons from astrocytes and thus the quantification of neuronal survival, especially in cocultures. Enzyme-linked immunosorbent assay (ELISA) analysis was performed as described previously (Théry et al., 1991). After washing with warmed PBS, cells were first fixed $\left(1 \mathrm{hr}\right.$ at $\left.4^{\circ} \mathrm{C}\right)$ with paraformaldehyde (4\% in PBS, $\left.\mathrm{pH} 7.4\right)$ and washed twice with PBS containing glycine $(0.1 \mathrm{M})$ and then twice with PBS-Tween $20(0.1 \%)$. Cells were then incubated $\left(1 \mathrm{hr}\right.$ at $\left.37^{\circ} \mathrm{C}\right)$ in PBS-Tween supplemented with $10 \%$ fetal calf serum (buffer A) and after washing, further incubated with mouse monoclonal anti-MAP-2 antibodies (IgG1) diluted (1/4000) in buffer A. After extensive washing, cells were finally incubated for $1 \mathrm{hr}$ at $37^{\circ} \mathrm{C}$ with peroxidase-coupled goat-antimouse $\operatorname{IgG}(1 / 3000$ in buffer $\mathrm{A})$. After washing, bound peroxidase was visualized by incubating for $5 \mathrm{~min}$ at $37^{\circ} \mathrm{C}$ the cells with $0.04 \%$ O-phenylenediamine and $0.012 \% \mathrm{H}_{2} \mathrm{O}_{2}$, diluted in citrate buffer, $\mathrm{pH} 5$. The reaction was stopped by adding $\mathrm{H}_{2} \mathrm{SO}_{4}$ to each well (final concentration $0.3 \mathrm{~N}$ ). Optical density was estimated at $490 \mathrm{~nm}$, and nonspecific binding (determined by substituting the buffer A for the anti-MAP-2 antibodies) was subtracted to obtain MAP-2-specific immunoreactivity.

\section{Determination of $\mathrm{H}_{2} \mathrm{O}_{2}$ concentration}

The concentrations of $\mathrm{H}_{2} \mathrm{O}_{2}$ remaining (or released) in the astrocytic or neuronal media after various incubation periods were estimated with a colorimetric assay. Conditioned media were centrifuged at 10,000$) \times \mathrm{g}$ for $2 \mathrm{~min}$, and $400 \mu \mathrm{l}$ of the supernatants were added to $200 \mu \mathrm{l}$ of $3,3^{\prime}$ dimethoxybenzidine $(2 \mathrm{~mm})$ and $200 \mu$ lof horseradish peroxidase $(240$ $\mathrm{IU} / \mathrm{ml}$ ). 3,3'-Dimethoxybenzidine, which is colorless in its reduced form, is oxidized in the presence of $\mathrm{H}_{2} \mathrm{O}_{2}$ and peroxidase into a red-colored product. Optical density was estimated at $500 \mathrm{~nm}$. The concentrations of $\mathrm{H}_{2} \mathrm{O}_{2}$ in conditioned media were determined using standard solutions.

\section{Assay for glutathione peroxidase activity and total glutathione}

Neurons or astrocytes cultured in $100 \mathrm{~mm}$ petri dishes were washed in PBS, collected in Versene, and centrifuged for $10 \mathrm{~min}$ at $200 \times \mathrm{g}$. Cell pellets were resuspended and homogenized in $50 \mu \mathrm{l}$ of ice-cold lysing buffer containing $50 \mathrm{~mm}$ Tris- $\mathrm{HCl}, \mathrm{pH} 7.5,3 \mathrm{~mm}$ EDTA, $100 \mu \mathrm{M}$ phenylmethyl-sulfonylfluoride, and $1 \%$ Triton X-100. Samples were then centrifuged for $6 \mathrm{~min}$ at $450,000 \times \mathrm{g}$, and supernatants were finally stored at $-20^{\circ} \mathrm{C}$ before use. Glutathione peroxidase activity was determined according to the method described by Flohé and Günzler (1984). Briefly, the following solution was preincubated for $10 \mathrm{~min}$ in the absence or presence of $5 \mathrm{~mm}$ 3-amino-1,2,4-triazole (ATZ) or $0.3 \mathrm{~mm}$ diethyl maleate (DEM): $50 \mathrm{~mm}$ phosphate buffer, pH 7.0,0.5 mM EDTA, and $0.5 \mathrm{~mm}$ sodium azide, cell supernatants $(\sim 20 \mu \mathrm{g}$ proteins, Triton X-100 final concentration: $0.005 \%), 0.24 \mathrm{IU} / \mathrm{ml}$ glutathione reductase, $1 \mathrm{~mm}$ glutathione (GSH), and $0.15 \mathrm{mM} \beta$-nicotinamide adenine dinucleotide phosphate (NADPH). The overall reaction was started by adding $0.15 \mathrm{~mm}$ $\mathrm{H}_{2} \mathrm{O}_{2}$, and the change in absorbance of NADPH at $340 \mathrm{~nm}\left(\epsilon_{340}=6220\right.$ $1 \cdot$ mole $^{-1} \cdot \mathrm{cm}^{-1}$ ) was monitored for $5 \mathrm{~min}$. The nonenzymatic reaction rate, assessed by replacing the cell supernatant by buffer, was subtracted from the observed rate. The activity was expressed in nmoles of $\mathrm{H}_{2} \mathrm{O}_{2}$ consumed/min/mg of protein contained in the sample, which was equivalent to the NADPH consumption.

To determine the total content of glutathionc, cell pellets were treated by adding $100 \mu \mathrm{l}$ of $1 \mathrm{M}$ perchloric acid containing $2 \mathrm{~mm}$ EDTA. Acid extracts were then centrifuged at $12,000 \times g$ for $5 \mathrm{~min}$ to remove proteins, and supernatants were neutralized with a solution containing $2 \mathrm{M} \mathrm{KOH}$ and $0.3 \mathrm{M} \mathrm{N}$-morpholinopropanesulfonic acid. Finally, glutathione content was determined according to the method of Tietze (1969).

\section{Assay for catalase activity}

Catalase activity was cstimated by the method of Acbi (1984). Samples, prepared as described above, were diluted $(1 / 100)$ in $50 \mathrm{~mm}$ phosphate buffer, $\mathrm{pH}$ 7.0. Six hundred microliters of this solution ( $\sim 12 \mu \mathrm{g}$ proteins) were added to $300 \mu \mathrm{l}$ of buffer containing $30 \mathrm{mM} \mathrm{H}_{2} \mathrm{O}_{2}$, and the decomposition of $\mathrm{H}_{2} \mathrm{O}_{2}$ was directly estimated by the decrease in absorbance at $240 \mathrm{~nm}\left(\epsilon_{240}=39.4 \mathrm{l} \cdot \mathrm{mole}^{-1} \cdot \mathrm{cm}^{-1}\right)$, recorded for $2 \mathrm{~min}$ in the absence or presence of $5 \mathrm{~mm} \mathrm{ATZ}$ or $0.3 \mathrm{~mm} \mathrm{DEM}$. The kinetics of the catalase reaction does not follow the normal pattern because it is not possible to saturate the enzyme with the substrate within the feasible concentration range (up to $5 \mathrm{M} \mathrm{H}_{2} \mathrm{O}_{2}$ ). Therefore, the catalase-induced decomposition of $\mathrm{H}_{2} \mathrm{O}_{2}$ apparently follows first-order kinetics (Aebi, 1984). For this 
reason, the specific activity of the enzyme was expressed as the first-order rate constant, $k$, divided by the weight of protein $\left(\mathrm{min}^{-1} \cdot \mathrm{mg}^{-1}\right.$ protein). The constant $k$ was calculated by dividing the initial slope $\left(\left[\mathrm{H}_{2} \mathrm{O}_{2}\right]\right.$ decrease/min) by the initial concentration of $\mathrm{H}_{2} \mathrm{O}_{2}(10 \mathrm{mM})$.

Protein concentration was estimated by the method of Bradford (1976).

\section{RESULTS}

\section{Kinetic characteristics of the}

\section{$\mathrm{H}_{2} \mathrm{O}_{2}$-induced neurotoxicity}

As previously observed with cultured cortical neurons (Théry et al., 1991; Whittemore et al., 1994), the 30 min exposure of striatal nèurons to $\mathrm{H}_{2} \mathrm{O}_{2}$ led to a concentration-dependent $(10-1000 \mu \mathrm{M})$ decrease of cell viability as estimated $24 \mathrm{hr}$ later. The potency and efficacy of the $\mathrm{H}_{2} \mathrm{O}_{2}$-induced toxicity were identical, regardless of the method used to estimate the neuronal survival of pure culture of striatal neurons [i.e., MTT assay or an ELISA with antibodies directed against an antigen located in neurons (MAP-2)] (Fig. 1).

After a $30 \mathrm{~min}$ exposure to $100 \mu \mathrm{M} \mathrm{H}_{2} \mathrm{O}_{2}$, the neuronal survival was $45 \pm 7 \%$ of the control (mean \pm SD obtained from 24 independent experiments performed in triplicate). Increasing the time of exposure of the striatal neurons to $100 \mu \mathrm{M} \mathrm{H}_{2} \mathrm{O}_{2}$ progressively decreased the cell viability as estimated $24 \mathrm{hr}$ later (Fig. 1).

The toxic effect of $100 \mu \mathrm{M} \mathrm{H} \mathrm{H}_{2} \mathrm{O}_{2}$ was totally prevented by catalase $(200 \mathrm{IU} / \mathrm{ml})$ or glutathione peroxidase $(5 \mathrm{IU} / \mathrm{ml}$ in the presence of $500 \mu \mathrm{M}$ reduced glutathione), but not by superoxide dismutase $(500 \mathrm{IU} / \mathrm{ml})$ (Table 1$)$

$\mathrm{H}_{2} \mathrm{O}_{2}$ has been shown to increase the release of $\mathrm{D}-\left[{ }^{3} \mathrm{H}\right]$ aspartate from cortical synaptosomes (Gilman et al., 1994). Therefore, the neurotoxic effect of $\mathrm{H}_{2} \mathrm{O}_{2}$ could indirectly be mediated by an excitotoxic amino acid. However, in contrast to that observed with 12-d-old neurons (Marin et al., 1994), the $30 \mathrm{~min}$ exposure of 6 -d-old striatal neurons (identical to those used in the present study) to glutamate (up to $200 \mu \mathrm{M}$ ) induced $<15 \%$ of cell death as estimated $24 \mathrm{hr}$ later (our unpublished observations). Moreover, the $\mathrm{H}_{2} \mathrm{O}_{2}$-induced neurotoxicity was not prevented by the glutamate ionotropic receptor antagonists APV ( $1 \mathrm{~mm}$ ) and DNQX (10 $\mu \mathrm{M})$ (Table 2).

\section{Respective roles of catalase and glutathione peroxidase in the modulation of the $\mathrm{H}_{2} \mathrm{O}_{2}$-induced neurotoxicity}

Enzymatic and nonenzymatic processes can contribute to the degradation of $\mathrm{H}_{2} \mathrm{O}_{2}$. Catalase and glutathione peroxidase are responsible for the enzymatic clearance of $\mathrm{H}_{2} \mathrm{O}_{2}$ (Coyle and Puttfarcken, 1993; Makino et al., 1994). Therefore, the ability of striatal neurons to remove $\mathrm{H}_{2} \mathrm{O}_{2}$ and the respective roles of these enzymes in this process were successively determined.

Cultured striatal neurons $\left(4 \times 10^{5}\right.$ cells seeded per well corresponding to $\sim 20 \mu \mathrm{g}$ proteins) were preincubated for increasing times with $100 \mu \mathrm{M} \mathrm{H}_{2} \mathrm{O}_{2}$. The incubating medium corresponding to each incubating period was then transferred onto other striatal neurons for an additional $30 \mathrm{~min}$ incubation. In each case, the cell survival of this second neuronal culture was then estimated $24 \mathrm{hr}$ later. In fact, increasing the preincubation time of neurons in the presence of $\mathrm{H}_{2} \mathrm{O}_{2}$ decreased the ncurotoxic effect of the corresponding conditioned media (Fig. 2), probably reflecting a decline in the extracellular level of the oxidant. Indeed, the concentration of $\mathrm{H}_{2} \mathrm{O}_{2}$ remaining in each conditioned medium progressively decreased with increasing preincubation times, demonstrating the clearance of extracellular $\mathrm{H}_{2} \mathrm{O}_{2}$ by neurons (Fig. 2). It must be noted that the spontaneous degradation rate of $100 \mu \mathrm{M} \mathrm{H} \mathrm{H}_{2} \mathrm{O}_{2}$ in the incubation buffer was $<1 \%$ after $1 \mathrm{hr}$ at $37^{\circ} \mathrm{C}$.

As estimated after a 15 min preincubation, the capacity of

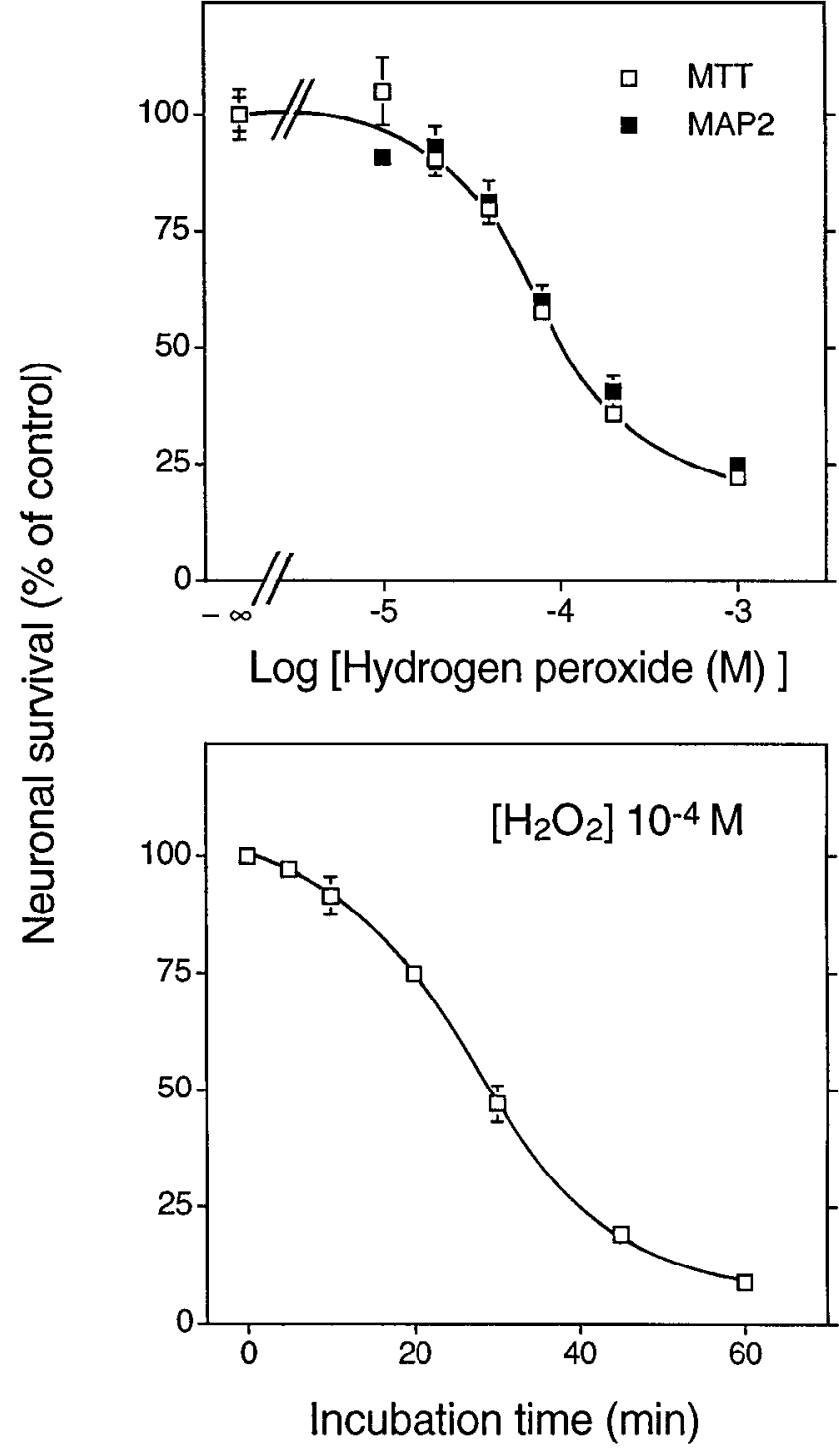

Figure 1. Kinetic characteristics of the neurotoxic effect of $\mathrm{H}_{2} \mathrm{O}_{2}$. Top, Primary cultures of striatal neurons were exposed for $30 \mathrm{~min}$ to increasing concentrations of $\mathrm{H}_{2} \mathrm{O}_{2}$. Neuronal survival was estimated $24 \mathrm{hr}$ later using both the MTT colorimetric assay and an ELISA with anti-MAP-2 antibodies. Data are the mean \pm SEM of triplicate determinations obtained in a typical experiment representative of three independent experiments performed with different cultures. Bottom, Neurons were incubated for increasing times with $100 \mu \mathrm{M} \mathrm{H} \mathrm{H}_{2} \mathrm{O}_{2}$, and neuronal survival was estimated with the MTT colorimetric assay 24 hr later. Data are the mean \pm SEM of three independent experiments performed in triplicate. Results are expressed as the percentage of surviving neurons compared with control cultures not treated with $\mathrm{H}_{2} \mathrm{O}_{2}$. When not visible, the sizes of the error bars are less than those of the symbols.

striatal neurons to remove external $\mathrm{H}_{2} \mathrm{O}_{2}(100 \mu \mathrm{M})$ was $46 \pm 6$ nmoles/mg protein/min (mean value $\pm \mathrm{SD}$ of three independent experiments performed in triplicate).

The effects of inhibitors of catalase or glutathione peroxidase were then examined to distinguish the respective contributions of these hydrogen peroxidase activities in the clearance of $\mathrm{H}_{2} \mathrm{O}_{2}$ ATZ has been shown to irreversibly inactivate catalase (Schonbaum and Chance, 1976). Because specific inhibitors of glutathione peroxidase are not yet available, DEM is generally used to indirectly decrease the activity of glutathione peroxidase. In fact, DEM depletes glutathione from the cells via a reaction catalyzed 
Table 1. Catalase and glutathione peroxidase but not superoxide dismutase prevented $\mathrm{H}_{2} \mathrm{O}_{2}$-induced neurotoxicity

\begin{tabular}{lc} 
Treatment & $\begin{array}{c}\text { Neuronal survival } \\
\text { (\% of control) }\end{array}$ \\
\hline $\mathrm{H}_{2} \mathrm{O}_{2}$ & $56 \pm 5$ \\
$\mathrm{H}_{2} \mathrm{O}_{2}+$ SOD & $55 \pm 1$ \\
$\mathrm{H}_{2} \mathrm{O}_{2}+$ catalase & $93 \pm 1$ \\
$\mathrm{H}_{2} \mathrm{O}_{2}+\mathrm{GPx}+\mathrm{GSH}$ & $100 \pm 9$
\end{tabular}

Striatal ncurons werc cxposed to $100 \mu \mathrm{M} \mathrm{H} \mathrm{H}_{2} \mathrm{O}_{2}$ for $30 \mathrm{~min}$ in the absence or presence of sụperoxide dismutase (SOD, $500 \mathrm{IU} / \mathrm{ml})$, catalase $(200 \mathrm{IU} / \mathrm{ml})$, or glutathione peroxidase $(\mathrm{GPx}, 5 \mathrm{IU} / \mathrm{ml})$ with $500 \mu \mathrm{m}$ reduced glutathione (GSH). Neuronal survival was estimated $24 \mathrm{hr}$ later with the MTT colorimetric assay. Neither SOD, catalase, nor GPx + GSH significantly changed neuronal survival in the absence of $\mathrm{H}_{2} \mathrm{O}_{2}$. Results are expressed as the percentage of surviving neurons compared with control cultures not treated with $\mathrm{H}_{2} \mathrm{O}_{2}$. Values are the means + SD of data obtained in two independent experiments performed in triplicate.

by glutathione S-transferase (Plummer et al., 1981; Meister, 1988). As expected, $0.3 \mathrm{~mm}$ DEM did not directly inhibit the activity of glutathione peroxidase in homogenates of striatal neurons (Table 3 ), but effectively decreased by $70 \%$ the neuronal content of glutathione (Table 3 ). In addition, we verificd that 5 mM ATZ did inhibit (by $86 \%$ ) the activity of catalase in neuronal homogenates and altered neither the activity of glutathione peroxidase nor the neuronal content of glutathione (Table 3).

The neurotoxicity of increasing concentrations of $\mathrm{H}_{2} \mathrm{O}_{2}$ was estimated in the absence or presence of either $5 \mathrm{mM} \mathrm{ATZ}$ or 0.3 mM DEM. The inhibition of glutathione peroxidase by DEM increased the $\mathrm{H}_{2} \mathrm{O}_{2}$ loxicity. Indeed, after a $30 \mathrm{~min}$ incubation of neurons with $10 \mu \mathrm{M} \mathrm{H}_{2} \mathrm{O}_{2}$, no significant cell death was observed, whereas in DEM-treated neurons, a 35\% decrease in the cell viability was detected (Fig. 2). In addition, DEM enhanced the neurotoxicity induced by higher concentrations of $\mathrm{H}_{2} \mathrm{O}_{2}$ (up to $100 \mu \mathrm{M}$ ) (Fig. 2). On the contrary, even in the presence of DEM, ATZ did not alter the $\mathrm{H}_{2} \mathrm{O}_{2}$-induced neurotoxicity (Fig. 2).

As expected, for an initial added concentration of $20 \mu \mathrm{M}$, the level of $\mathrm{H}_{2} \mathrm{O}_{2}$ remaining in the external medium after a $45 \mathrm{~min}$ incubation was doubled $(5-10 \mu \mathrm{M})$ when striatal neurons were pretreated with DEM, but a pretreatment by ATZ was ineffective.

Therefore, in our culture conditions, the neuronal defense against $\mathrm{H}_{2} \mathrm{O}_{2}$ toxicity appears to be mediated primarily by glutathione peroxidase. This conclusion was further confirmed by experiments in which $\mathrm{H}_{2} \mathrm{O}_{2}$ was endogenously produced using menadione (2-methyl-1,4-naphthoquinone). Indeed, via the redox cycling of quinonoid drugs, menadione leads to the formation of superoxide anions whose enzymatic or spontane-

Table 2. Lack of protection of glutamate ionotropic receptor antagonists against $\mathrm{H}_{2} \mathrm{O}_{2}$-induced neurotoxicity

\begin{tabular}{ll} 
Treatment & $\begin{array}{l}\text { Neuronal survival } \\
\text { (\% of control) }\end{array}$ \\
\hline $\mathrm{H}_{2} \mathrm{O}_{2}$ & $42 \pm 2$ \\
$\mathrm{H}_{2} \mathrm{O}_{2}+$ APV & $42 \pm 1$ \\
$\mathrm{H}_{2} \mathrm{O}_{2}+$ DNQX & $37 \pm 1$ \\
$\mathrm{H}_{2} \mathrm{O}_{2}+\Lambda P V+$ DNQX & $35 \pm 2$
\end{tabular}

Pure neuronal cultures were preincubated for $30 \mathrm{~min}$ with the competitive NMDA receptor antagonist APV (1 mM) or the AMPA receptor antagonist DNQX $(10 \mu \mathrm{M})$ or both, and then incubated for $30 \mathrm{~min}$ with $100 \mu \mathrm{M} \mathrm{H} \mathrm{H}_{2} \mathrm{O}_{2}$ in either the absence or presence of the antagonists. Neuronal survival was estimated $24 \mathrm{hr}$ later using the MTT colorimetric assay. Results are the means \pm SEM of triplicate determinations obtained in a typical experiment representative of three experiments performed with different cultures.

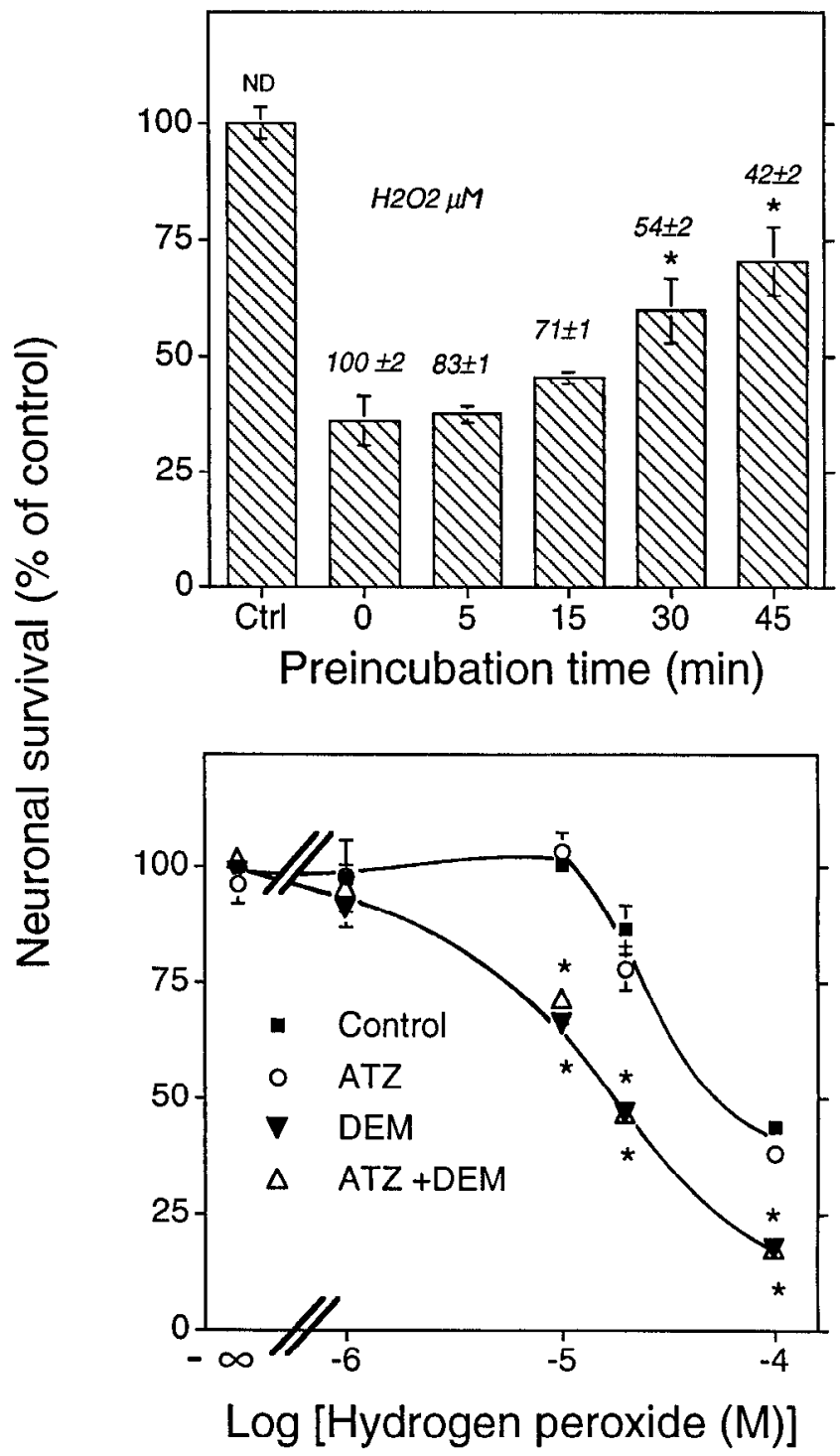

Figure 2. Neuronal enzymatic activities involved in the protection against $\mathrm{H}_{2} \mathrm{O}_{2}$-induced toxicity. Top, Cultured striatal neurons were preincubated for increasing times (Preincubation time) with $100 \mu \mathrm{M}$ $\mathrm{H}_{2} \mathrm{O}_{2}$. Conditioned media, corresponding to cach prcincubation time, were then collected and transferred onto another neuronal culture for a $30 \mathrm{~min}$ incubation. Control $(\mathrm{Ctrl})$ refers to a medium conditioned for 45 min without $\mathrm{H}_{2} \mathrm{O}_{2}$. Neuronal survival of the second culture was estimated $24 \mathrm{hr}$ later using the MTT colorimetric assay. In the presented experiment, each well contained $17.5 \mu \mathrm{g}$ proteins. Remaining concentrations of $\mathrm{H}_{2} \mathrm{O}_{2}(\mu \mathrm{M})$ estimated in the conditioned medium corresponding to each preincubation time are indicated above the bars; $N D$, Nondetectable. ${ }^{*} p<0.01$; significantly different from the neuronal survival value obtained with unconditioned medium referred to as the 0 time of preincubation (ANOVA followed by Dunnett's test). Bottom, Striatal neurons were preincubated for $1 \mathrm{hr}$ without (Control) or with the hydrogen peroxidases inhibitors ( $5 \mathrm{mM} A T Z, 0.3 \mathrm{~mm} D E M$, or both) and then further incubated for $30 \mathrm{~min}$ with increasing concentrations of $\mathrm{H}_{2} \mathrm{O}_{2}$ in either the presence or the absence of the inhibitors. Ncuronal survival was estimated $24 \mathrm{hr}$ later using the MTT colorimetric assay. For simplification and clarity, only the curves for Control and DEM are showII. ${ }^{*} p<0.01$; significantly different from the corresponding values determined in the absence of inhibitors (ANOVA followed by Dunnett's test). Results are expressed as the percentage of surviving neurons compared with control cultures not treated with $\mathrm{H}_{2} \mathrm{O}_{2}$. Data are the mean \pm SEM of triplicate determinations obtained in a typical experiment representative of three experiments performed with different cultures. When not visible, the sizes of the error bars are less than those of the symbols. 
Table 3. Glutathione cell content and catalase and glutathione
peroxidase activities in homogenates from striatal neurons or astrocytes

\begin{tabular}{llc} 
Treatment & Astrocytes & Neurons \\
\hline & Catalasc activity: $\mathrm{k}\left(\mathrm{min}^{-1} \cdot \mathrm{mg}^{-1}\right.$ protein $)$
\end{tabular}

Control

DEM

ATZ

$$
\begin{aligned}
& 19.5 \pm 4.0 \\
& 18.6 \pm 2.7
\end{aligned}
$$

$4.3 \pm 0.3$

$4.7 \pm 0.3$

$1.8 \pm 1.1^{*}$

$0.6 \pm 0.1^{*}$

Glutathione peroxidase activity (nmol $\mathrm{H}_{2} \mathrm{O}_{2} / \mathrm{min}^{-1} \cdot \mathrm{mg}^{-1}$ protein)

\begin{tabular}{lcc} 
Control & $103 \pm 7$ & $23 \pm 3$ \\
DFM & $84 \pm 7$ & $25 \pm 2$ \\
ATZ & $104 \pm 5$ & $24 \pm 3$ \\
& \multicolumn{1}{c}{ Glutathione content (nmol/mg protein) } \\
\cline { 2 - 3 } & $18 \pm 2$ & $33 \pm 2$ \\
Control & $3 \pm 1^{*}$ & $10 \pm 2^{*}$ \\
DEM & $20 \pm 1$ & $31 \pm 5$ \\
ATZ &
\end{tabular}

Catalase and glutathione peroxidase activities and glutathione cell content were assayed and expressed as indicated in Materials and Methods in the absence or presence of $5 \mathrm{~mm} \mathrm{ATZ}$ or $0.3 \mathrm{~mm}$ DEM. Values are the means \pm SD of two independent experiments perfomed in triplicate. ${ }^{*} p<0.05$; significantly different from the corresponding control value (ANOVA followed by Dunnett's test).

ous dismutation is responsible for $\mathrm{H}_{2} \mathrm{O}_{2}$ formation (Thor et al., 1982; White and Clark, 1988). In fact, a $30 \mathrm{~min}$ incubation of striatal neurons with increasing concentrations of menadione induced a progressive cell death (Fig. 3). Consistent with the major role of glutathione peroxidase, when menadione was used at its threshold effective concentration $(20 \mu \mathrm{M})$, its neurotoxic effect was unmasked in the presence of $0.3 \mathrm{~mm}$ DEM, and an accumulation of $\mathrm{H}_{2} \mathrm{O}_{2}$ was detected in the extracellular medium (Fig. 4). This latter observation probably reflects the occurrence of an important intracellular production of $\mathrm{H}_{2} \mathrm{O}_{2}$ taking into account the very high difference between the intraand extracellular volumes. In contrast, $5 \mathrm{mM}$ ATZ neither significantly unmasked the neurotoxic effect of the threshold concentration of menadione nor induced any $\mathrm{H}_{2} \mathrm{O}_{2}$ accumulation in the extracellular medium (Fig. 4).

\section{Protective role of striatal astrocytes against $\mathrm{H}_{2} \mathrm{O}_{2}$-induced neurotoxicity}

To look for a putative neuroprotective role of astrocytes against $\mathrm{H}_{2} \mathrm{O}_{2}$, the neurotoxicity of $\mathrm{H}_{2} \mathrm{O}_{2}$ was assessed using astrocytoneuronal cocultures. Preliminary experiments indicated that the viability of striatal astrocytes is not affected $24 \mathrm{hr}$ after a $1 \mathrm{hr}$ exposure of these cells to $\mathrm{H}_{2} \mathrm{O}_{2}$ (up to $1 \mathrm{~mm}$ ) (not shown).

In striatal cocultures, the neuronal survival was determined using an ELISA with antibodies directed against an antigen selectively located in neurons (MAP-2). Compared with that observed on a pure neuronal population, the neurotoxic effects of 30 and $100 \mu \mathrm{M} \mathrm{H}_{2} \mathrm{O}_{2}$ were respectively suppressed and markedly decreased in astrocytoneuronal cocultures made up of $5 \times 10^{4}$ astrocytes per $4 \times 10^{5}$ neurons plated per well (Fig. 5).

The protective effect of astrocytes depended on their seeding density (Table 4 ). Under the culture conditions used, $\sim 40 \%$ of the seeded neurons died during the first $6 \mathrm{~d}$ in culture (Birman et al., 1989). It can thus be calculated that a significant neuroprotection is detectable for 1 astrocyte to $\sim 20$ neurons (1:20) present at the time of the experiment (Table 4). On the contrary, neurons

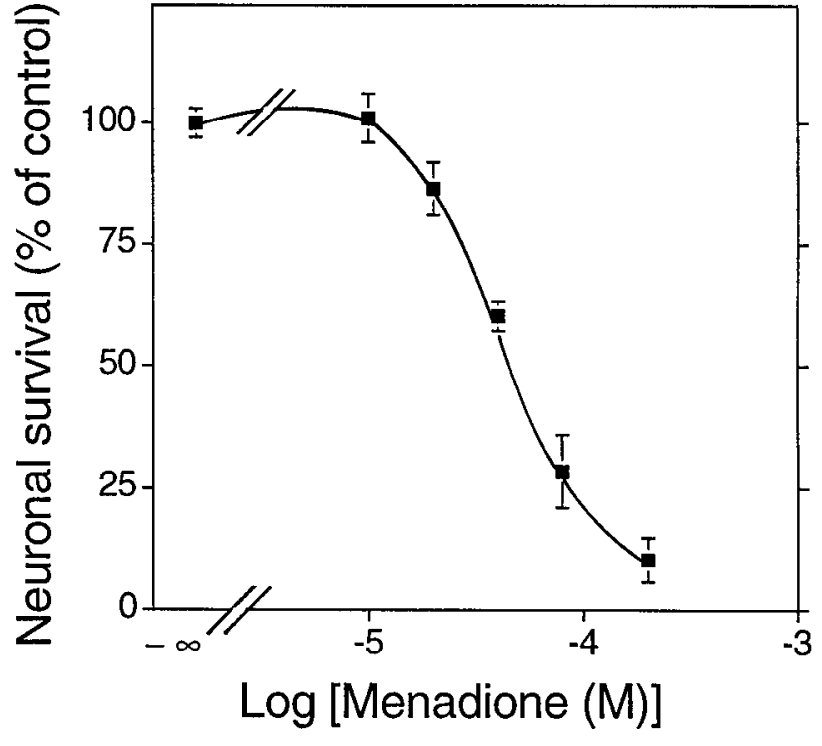

Figure 3. Neurotoxic effects of menadione. Primary cultures of striatal neurons were incubated for $30 \mathrm{~min}$ with increasing concentrations of menadione. Neuronal survival was measured 24 hr later using the MTT colorimetric assay. Results are expressed as the percentage of surviving neurons compared with control cultures not treated with monadionc. Data are the mean \pm SD of two experiments performed in triplicate.

did not seem to protect each other because the toxic effect of 100 $\mu \mathrm{M} \mathrm{H}_{2} \mathrm{O}_{2}$ was not significantly changed at any neuronal seeding density tested (2-6 $\times 10^{5}$ cells per well) (Table 4$)$.

Further revealing the prominent protective role of astrocytes, the neurotoxic effect of astrocytic-conditioned media, obtained by preincubating $100 \mu \mathrm{M} \mathrm{H}_{2} \mathrm{O}_{2}$ with astrocytes $\left(5 \times 10^{4}\right.$ cells per well corresponding to $6 \mu \mathrm{g}$ proteins), rapidly decreased when these cells were preincubated for increasing times (Fig. 6). This probably reflects the clearance of $\mathrm{H}_{2} \mathrm{O}_{2}$ by astrocytes, as indicated by the concomitant decrease of $\mathrm{H}_{2} \mathrm{O}_{2}$ concentrations in the conditioned media (Fig. 6). When the neurotoxic effects of the concentrations of $\mathrm{H}_{2} \mathrm{O}_{2}$ remaining in the astrocytic-conditioned media were compared with those induced by various concentrations of $\mathrm{H}_{2} \mathrm{O}_{2}$ directly added to neurons, no significant difference could be observed (Fig. 6). This suggests that the protective effect of astrocytes is mainly related to their intrinsic capacity to remove $\mathrm{H}_{2} \mathrm{O}_{2}$ and not to a possible release of compounds that could protect neurons against $\mathrm{H}_{2} \mathrm{O}_{2}$-induced toxicity.

To confirm the latter conclusion, we tested the neurotoxic effects of increasing concentrations of $\mathrm{H}_{2} \mathrm{O}_{2}$ added to three different incubating media: (1) the fresh incubating standard buffer; (2) a conditioned medium obtained by preincubating astrocytes with $100 \mu \mathrm{M} \mathrm{H}_{2} \mathrm{O}_{2}$ for $2 \mathrm{hr}$ to completely remove the oxidant (the remaining $\mathrm{H}_{2} \mathrm{O}_{2}$ concentration was $<1 \mu \mathrm{M}$ ); and (3) a medium conditioned with astrocytes for $2 \mathrm{hr}$ without $\mathrm{H}_{2} \mathrm{O}_{2}$ (Fig. 7). If astrocytes released a neuroprotective compound either spontaneously or in the presence of $\mathrm{H}_{2} \mathrm{O}_{2}$, the neurotoxic effect of $\mathrm{H}_{2} \mathrm{O}_{2}$ should be decreased when tested in an astrocytic-conditioned medium. As shown in Figure 7, this was not the case, and this further supports the conclusion that the neuroprotective effect of astrocytes is mainly attributable to their capacity to clear external $\mathrm{H}_{2} \mathrm{O}_{2}$.

As estimated at the end of a 15 min incubation, the capacity of striatal astrocytes $\left(5 \times 10^{4}\right.$ per well $)$ to remove external $\mathrm{H}_{2} \mathrm{O}_{2}(100$ $\mu \mathrm{M}$ ) was $317 \pm 27 \mathrm{nmoles} / \mathrm{mg}$ protein $/ \mathrm{min}$ (mean $\pm \mathrm{SD}$ of three independent experiments performed in triplicate), which is ap- 

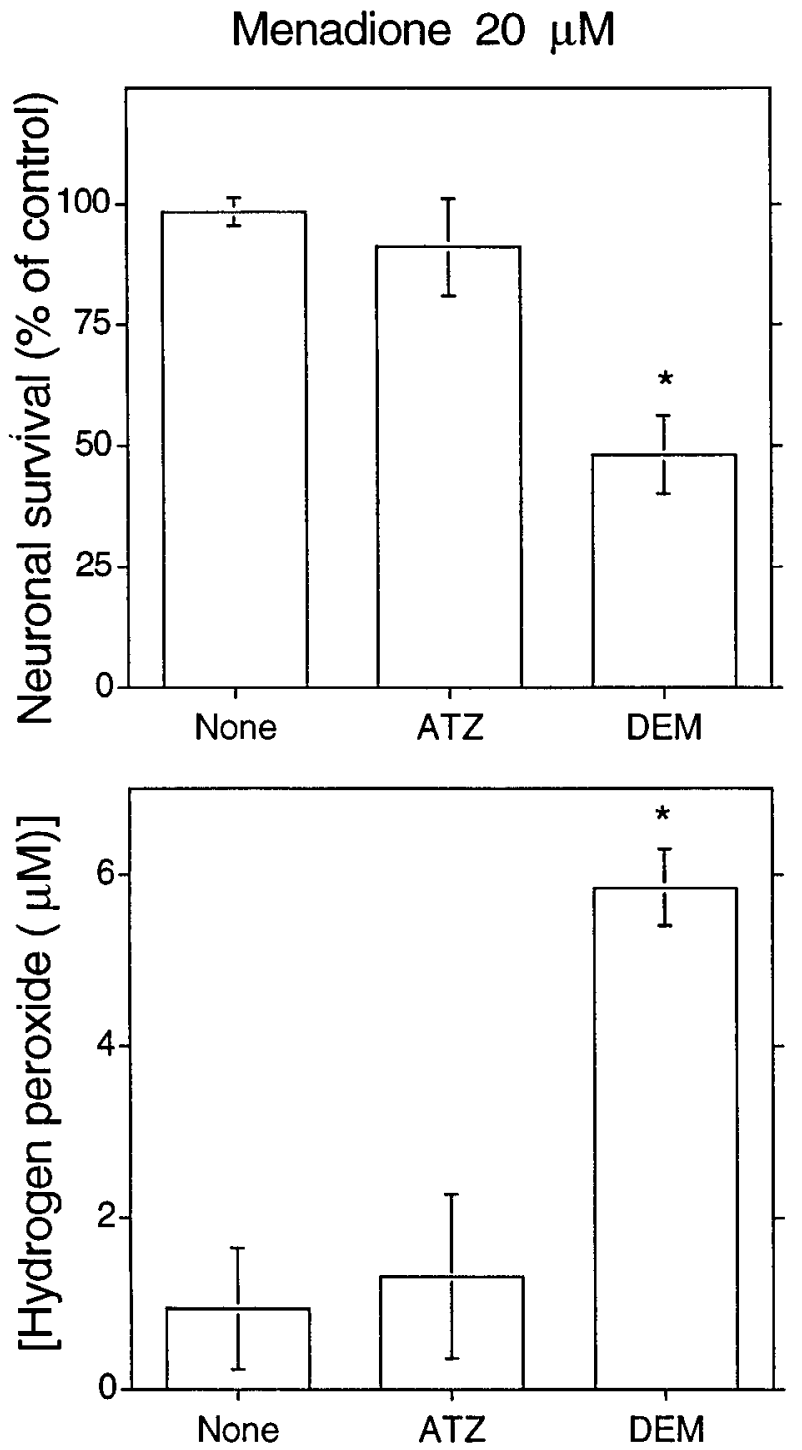

Figure 4. Modulation by hydrogen peroxidase inhibitors of the effects of menadione. Neurons were preincubated for $1 \mathrm{hr}$ with either $5 \mathrm{~mm} A T Z$ or $0.3 \mathrm{mM} D E M$ alone and then further incubated for $30 \mathrm{~min}$ with $20 \mu \mathrm{M}$ menadione in either the absence or the presence of the inhibitors. Top, Neuronal survival was estimated $24 \mathrm{hr}$ later using the MTT colorimetric assay. Results are expressed as the percentage of surviving neurons compared with control cultures not treated with menadione. Bottom, Concentrations of $\mathrm{H}_{2} \mathrm{O}_{2}(\mu \mathrm{M})$ in the different incubation media were estimated at the end of the 30 min incubation with menadione. $\mathrm{H}_{2} \mathrm{O}_{2}$ was not detectable in the medium of neurons incubated in the absence of menadione (not shown). Data are the mean $\pm \mathrm{SD}$ of two independent experiments performed in triplicate. ${ }^{*} p<0.01$; significantly different from the neuronal survival, or the $\mathrm{H}_{2} \mathrm{O}_{2}$ concentration present in the incubation medium, of neurons incubated with $20 \mu \mathrm{M}$ menadione in the absence of inhibitors (ANOVA followed by Dunnett's test).

proximately sevenfold higher than that measured with neuronal cultures. This observation is in accordance with the higher activities of catalase and glutathione peroxidase in homogenates from astrocytes than from neurons (Table 3). Indeed, these enzymatic activities were 4.5-fold higher in astrocytic than in neuronal homogenates, but this may not reflect the hydrogen peroxidase activities in the living cells. In fact, the content of glutathione was approximately twofold lower in astrocytes than in neurons (Table 3 ), likely leading to a reduced glutathione peroxidase activity in astrocytes. This difference in glutathione content could be related

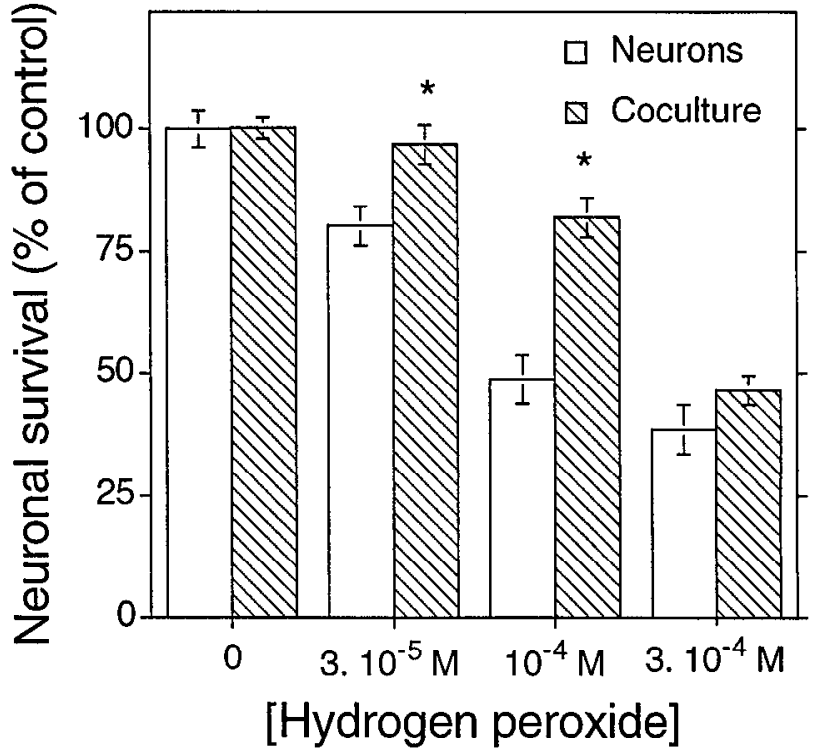

Figure 5. Protective effect of astrocytes cocultured with neurons on $\mathrm{H}_{2} \mathrm{O}_{2}$-induced neurotoxicity. Either pure cultures of neurons or a coculture consisting of $5 \times 10^{4}$ astrocytes and $4 \times 10^{5}$ neurons per well (see Materials and Methods) were exposed for $30 \mathrm{~min}$ to increasing concentrations of $\mathrm{H}_{2} \mathrm{O}_{2}$. Neuronal survival was estimated $24 \mathrm{hr}$ later using an ELISA with anti-MAP-2 antibodies. Results are expressed as the percentage of surviving neurons estimated in each experimental condition (in either the absence or the presence of astrocytes) in the absence of $\mathrm{H}_{2} \mathrm{O}_{2}$. An $18 \%$ increase of the MAP-2 content was observed when neurons were coculturcd with astrocytcs (not shown). Data arc the mean \pm SEM of three independent experiments performed in triplicate. ${ }^{*} p<0.05$; significantly different from the corresponding values determined on pure cultures of neurons (unpaired Student's $t$ test).

to the different compositions of the media used for the astrocytic and neuronal cultures. Supporting this statement, when astrocytes were cultured for the last $6 \mathrm{~d}$ in a medium similar to that of neurons, their content in glutathione increased, reaching a value (43 nmoles/mg protein) higher than that of neurons. Nevertheless, the activities of catalase and glutathione peroxidase in homoge-

Table 4. $\mathrm{H}_{2} \mathrm{O}_{2}$-induced neurotoxicity in the presence of different densities of astrocytes or neurons

Number of astrocytes $\left(\times 10^{-3}\right)$

cocultured with $4 \times 10^{5}$ neurons

per well

Neuronal survival

0 (\% of control)

12.

50

$53 \pm 7$

$70 \pm 1^{*}$

100

$81 \pm 1^{*}$

$85 \pm 4^{*}$

$97 \pm 1^{*}$

Number of neurons $\left(\times 10^{-3}\right)$ per well (without Neuronal survival astrocytes)

200 (\% of control)

400

$41 \pm 6$

600

$45 \pm 6$

$44 \pm 5$

Astrocytoneuronal cocultures or pure neuronal cultures were incubated for $30 \mathrm{~min}$ with $100 \mu \mathrm{M} \mathrm{H}_{2} \mathrm{O}_{2}$. Neuronal survival was estimated $24 \mathrm{hr}$ later using an ELISA with anti-MAP2 antibodies for cocultures or the MTT colorimetric assay for pure cultures. Data are the means \pm SEM of three independent experiments performed in triplicate. ${ }^{*} p<0.01$; significantly different from the corresponding values determined on pure cultures of neurons $\left(4 \times 10^{5}\right.$ neurons) (ANOVA followed by Dunnett's test). 

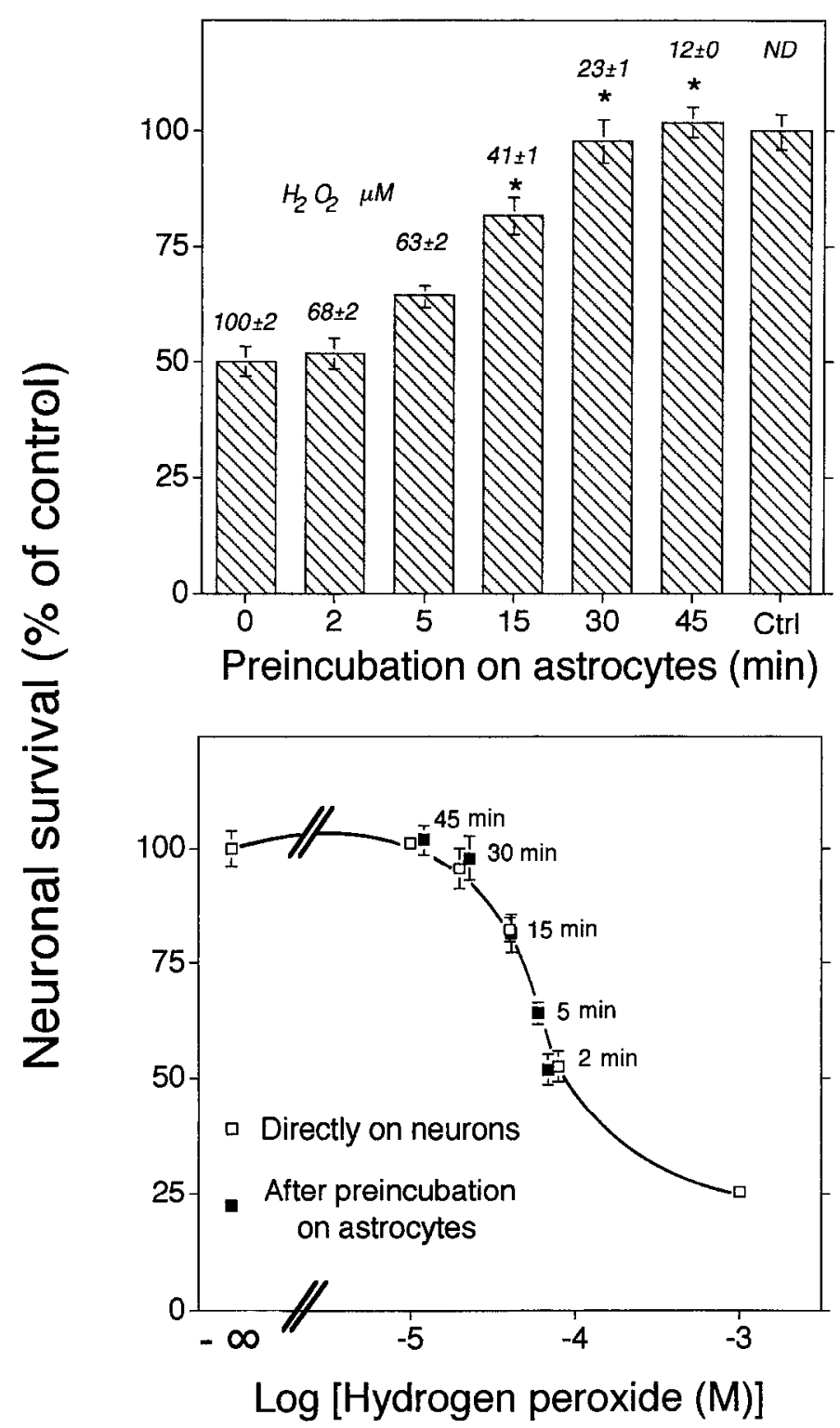

Figure 6. Clearance of $\mathrm{H}_{2} \mathrm{O}_{2}$ by astrocytes. Top, Cultured striatal astrocytes were preincubated for increasing times in the presence of $100 \mu \mathrm{M}$ $\mathrm{H}_{2} \mathrm{O}_{2}$. Conditioned media, corresponding to each preincubation time, were then collected and transferred onto a primary neuronal culture for a 30 min incubation. Remaining concentrations $(\mu \mathrm{M})$ of $\mathrm{H}_{2} \mathrm{O}_{2}$ in each conditioned medium are indicated above the bars. $N D$, Nondetectable. Control $(\mathrm{Ctrl})$ refers to the medium conditioned in the absence of added $\mathrm{H}_{2} \mathrm{O}_{2}$. Neuronal survival was estimated $24 \mathrm{hr}$ later using the MTT colorimetric assay. Compared with results obtained with the control unconditioned medium, the astrocytic-conditioned medium obtained after a 45 min incubation in the absence of $\mathrm{H}_{2} \mathrm{O}_{2}$ did not alter neuronal survival as estimated $24 \mathrm{hr}$ later (not shown). ${ }^{*} p<0.01$; significantly different from the neuronal survival value obtained with unconditioned medium referred to as the 0 time of preincubation (ANOVA followed by Dunnett's test). The bottom of the figure is partially derived from the top. The neurotoxicity induced by increasing concentrations of $\mathrm{H}_{2} \mathrm{O}_{2}$ added directly to neurons was compared with that observed in a sister culture that received the astrocytic-conditioned media (described above). In both cases, neuronal survival was plotted as the function of either the concentrations of $\mathrm{H}_{2} \mathrm{O}_{2}$ directly added or the remaining concentrations of $\mathrm{H}_{2} \mathrm{O}_{2}$ in the conditioned media (at the end of each indicated time of preincubation with $100 \mu \mathrm{M} \mathrm{H}_{2} \mathrm{O}_{2}$ ). Results are expressed as the percentage of surviving neurons compared with control cultures not treated with $\mathrm{H}_{2} \mathrm{O}_{2}$. Data are the mean \pm SEM of triplicate determinations obtained in a typical experiment representative of two experiments performed with different cultures.

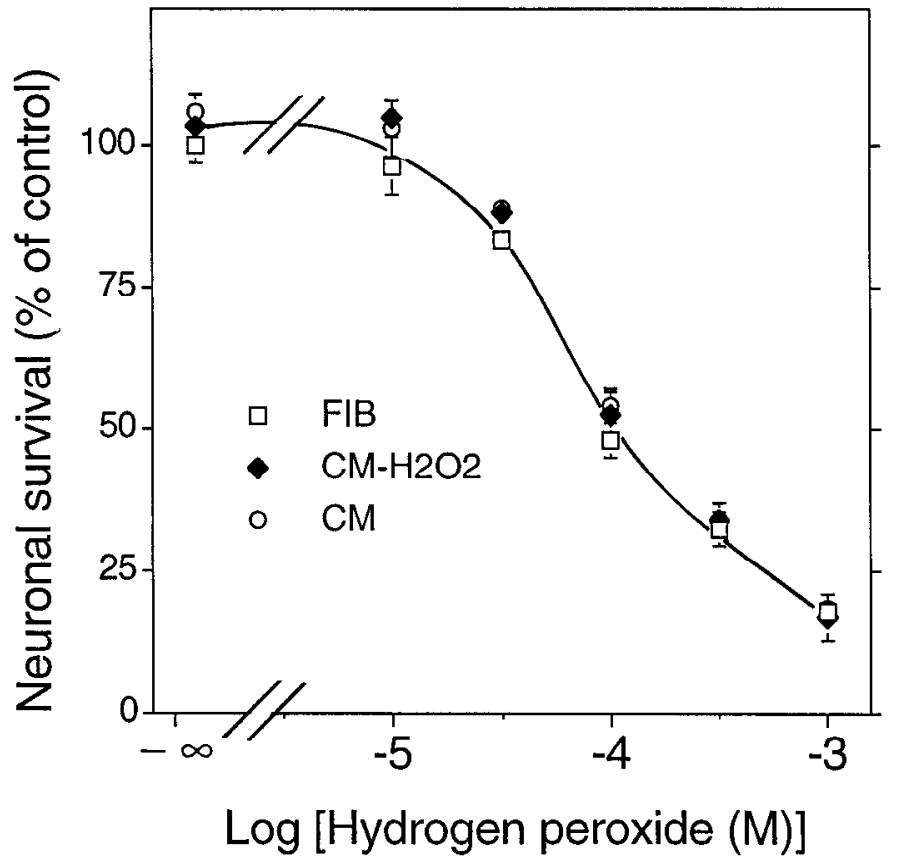

Figure 7. A putative protective compound released from astrocytes does not seem to be involved in the protecting effect of these cells against the $\mathrm{H}_{2} \mathrm{O}_{2}$-induced neurotoxicity. The neurotoxicity induced by increasing concentrations of $\mathrm{H}_{2} \mathrm{O}_{2}$ directly added to neurons was tested in three experimental conditions: using a fresh incubating buffer $(F I B)$ or conditioned media obtained by preincubating astrocytes for $2 \mathrm{hr}$ with the incubating buffer initially enriched (CM-H2O2), or not $(C M)$ with $100 \mu \mathrm{M} \mathrm{H}_{2} \mathrm{O}_{2}$. We verified that the remaining concentration of $\mathrm{H}_{2} \mathrm{O}_{2}$ present in the conditioned medium $\left(\mathrm{CM}-\mathrm{H}_{2} \mathrm{O}_{2}\right)$ was $<1 \mu \mathrm{M}$. Neurons were incubated for 30 min with these incubating media in which increasing concentrations of $\mathrm{H}_{2} \mathrm{O}_{2}$ were added. Neuronal survival was estimated $24 \mathrm{hr}$ later using the MTT colorimetric assay. Results are expressed as the percentage of surviving neurons compared with control cultures not treated with $\mathrm{H}_{2} \mathrm{O}_{2}$. Data are the mean $\pm \mathrm{SD}$ of two independent experiments performed in triplicate.

nates from these astrocytes did not significantly change $(21.3 \pm$ $1.9 \mathrm{~min}^{-1} \cdot \mathrm{mg}^{-1}$ protein and $104 \pm 1 \mathrm{nmol} \mathrm{H} \mathrm{O}_{2} / \mathrm{min} / \mathrm{mg}$ protein, respectively). Finally, as expected, when astrocytes were cultured in the neuronal medium, the inhibiting effect of DEM pretreatment on their capacity to clear extracellular $\mathrm{H}_{2} \mathrm{O}_{2}$ was increased, but it still remained significantly lower than that of ATZ (not shown)

\section{Respective roles of catalase and glutathione peroxidase in the protective effects of astrocytes against the $\mathrm{H}_{2} \mathrm{O}_{2}$-induced neurotoxicity}

The respective contributions of catalase and glutathione peroxidase in the capacity of striatal astrocytes to clear $\mathrm{H}_{2} \mathrm{O}_{2}$ from the extracellular medium were determined using a pharmacological strategy similar to that selected for neurons. Indeed, $5 \mathrm{~mm} \mathrm{ATZ}$ induced a $91 \%$ inhibition of catalase activity in the astrocytic homogenates, but modified neither the activity of glutathione peroxidase nor the cell content of glutathione (Table 3). In addition, $0.3 \mathrm{mM}$ DFM did not significantly alter the activity of glutathione peroxidase, but it decreased the astrocytic content of glutathione by $83 \%$ (Table 3 ).

The viability of striatal neurons was only slightly reduced when these cells were exposed for $30 \mathrm{~min}$ to a conditioned medium obtained by preincubating for $45 \mathrm{~min}$ astrocytes with $100 \mu \mathrm{M}$ $\mathrm{H}_{2} \mathrm{O}_{2}$ (Fig. 8). However, when astrocytes were pretreated with 5 

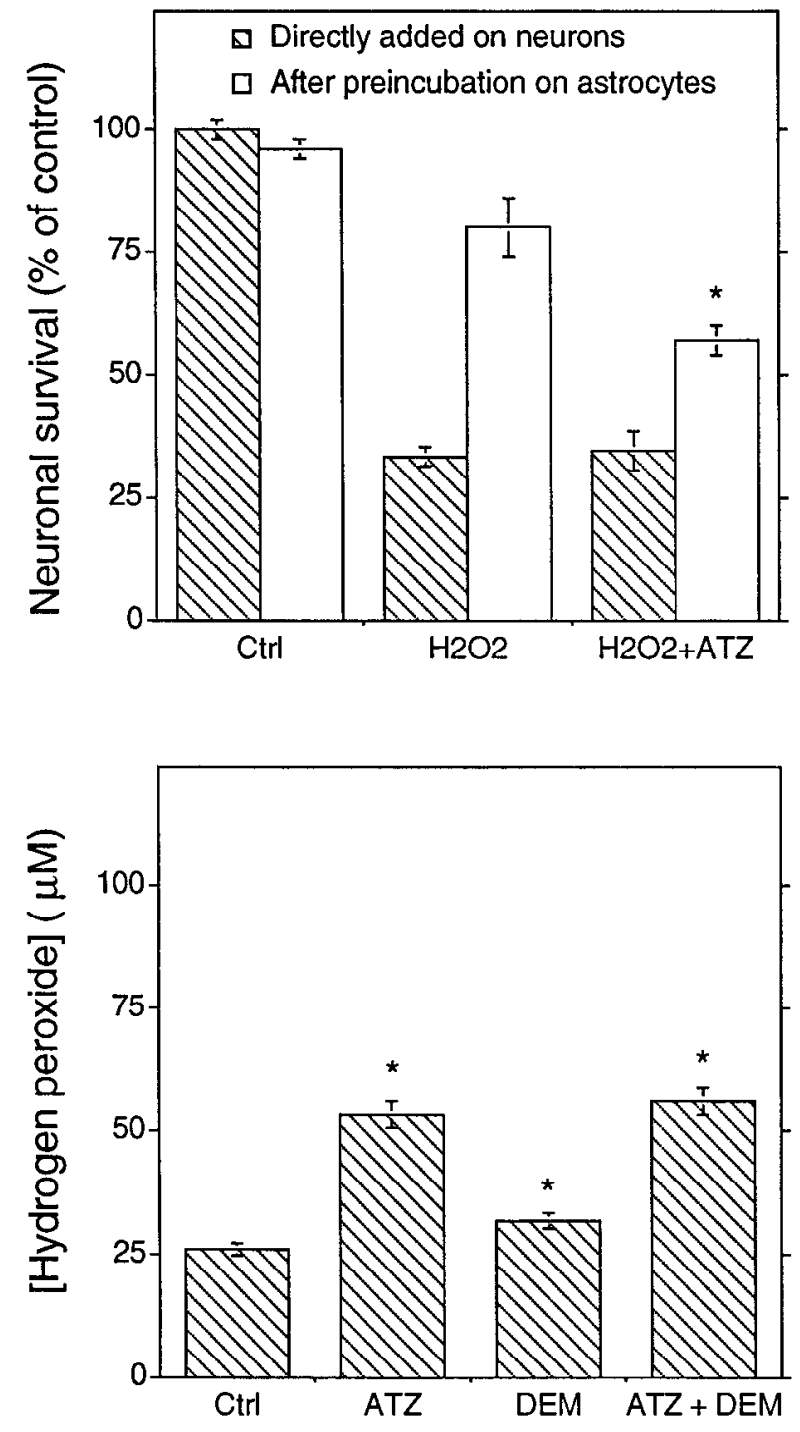

Figure 8. Catalase is involved in the protecting effect of astrocytes against the $\mathrm{H}_{2} \mathrm{O}_{2}$-induced neurotoxicity. Top, Primary cultures of striatal neurons were exposed for 30 min either to a $100 \mu \mathrm{M} \mathrm{H}_{2} \mathrm{O}_{2}$ solution without ( $\mathrm{H} 2 \mathrm{O} 2$ ) or with $5 \mathrm{~mm} \mathrm{ATZ}(\mathrm{H} 2 \mathrm{O} 2+A T Z)$ or to astrocytic-conditioned media. These media were obtained by preincubating for $4 \mathrm{hr}$ the astrocytes with either the control buffer or the buffer enriched with $5 \mathrm{mM} \mathrm{ATZ}$, and then by incubating the cells for $45 \mathrm{~min}$ with $100 \mu \mathrm{M} \mathrm{H}_{2} \mathrm{O}_{2}$ in the absence ( $\mathrm{H} 2 \mathrm{O} 2$ ) or the presence of $5 \mathrm{~mm}$ ATZ. Neuronal survival was estimated 24 hr later using the MTT colorimetric assay. Results are expressed as the percentage of surviving neurons compared with control cultures not treated with $\mathrm{H}_{2} \mathrm{O}_{2}(\mathrm{Ctrl})$. Bottom, Cultured astrocytes were preincubated for $4 \mathrm{hr}$ with either the control buffer or $5 \mathrm{mM} A T Z, 0.3 \mathrm{mM} D E M$, or both, and then incubated for 45 min with $100 \mu \mathrm{M} \mathrm{H}_{2} \mathrm{O}_{2}$ in either the absence $(C t r l)$ or the presence of ATZ and/or DEM $(A T Z+D E M)$. Conditioned media were then collected, and remaining $\mathrm{H}_{2} \mathrm{O}_{2}$ concentrations were estimated in each experimental condition. ${ }^{*} p<0.05$; significantly different from the value determined in the presence of $\mathrm{H}_{2} \mathrm{O}_{2}$ and in the absence of inhibitors (ANOVA followed by Dunnett's test). Data are the mean \pm SEM of three independent experiments performed in triplicate.

mM ATZ, the neurotoxic effect of the astrocytic-conditioned medium was largely increased (Fig. 8). Additional experiments in which the remaining concentrations of $\mathrm{H}_{2} \mathrm{O}_{2}$ were estimated after a $45 \mathrm{~min}$ incubation of the astrocytes initially exposed to $100 \mu \mathrm{M}$ $\mathrm{H}_{2} \mathrm{O}_{2}$ further supported this conclusion. Indeed, $5 \mathrm{~mm} \mathrm{ATZ}$ strongly decreased the clearance of $\mathrm{H}_{2} \mathrm{O}_{2}$ by astrocytes, whereas only a slight effect could be observed with the glutathione perox- idase inhibitor DEM (Fig. 8). Together, these results suggest that most of the hydrogen peroxidase activity in astrocytes is attributable to catalase, in the culture conditions used.

\section{DISCUSSION}

$\mathrm{H}_{2} \mathrm{O}_{2}$ originates from the enzymatic or spontaneous dismutation of superoxide anions, which are the byproducts of a wide and ubiquitous variety of oxidases (Cross and Jones, 1991). $\mathrm{H}_{2} \mathrm{O}_{2}$ has been known for a long time to be toxic for numerous cell types (Kim and Kim, 1991; Byler et al., 1994; Cantoni et al., 1994; Clapp et al., 1994). Because of its high membrane permeability (Halliwell, 1992; Makino et al., 1994), intracellularly formed $\mathrm{H}_{2} \mathrm{O}_{2}$ could induce its deleterious effects not only within its cell of origin, but also in neighboring cells. Recent reports indicate that neurons are particularly vulncrable to this mild oxidizing agent (Théry et al., 1991; Buckman et al., 1993; Behl et al., 1994; Whittemore et al., 1994). Because astrocytes contain high concentrations of antioxidant/antioxidant enzymes (Raps et al., 1989; Sagara et al., 1993; Makar et al., 1994), these cells could protect neurons from oxidative stress. This was demonstrated in the present study using cultured astrocytes and neurons from the mouse striatum. Indeed, because of their high hydrogen peroxidase activity, astrocytes were shown to protect neurons against the toxicity of exogenous $\mathrm{H}_{2} \mathrm{O}_{2}$.

$\mathrm{H}_{2} \mathrm{O}_{2}$ induced the cell death of cultured striatal neurons in a range of concentrations similar to that observed for neurons from the cerebral cortex (Théry et al., 1991; Whittemore et al., 1994). In our experimental conditions, when applied onto a pure culture of striatal neurons, $100 \mu \mathrm{M} \mathrm{H}_{2} \mathrm{O}_{2}$ induced an $\sim 55 \%$ decrease in the survival of these cells. However, at the same concentration, $\mathrm{H}_{2} \mathrm{O}_{2}$ was almost devoid of neurotoxic effect on striatal ncurons cocultured for $24 \mathrm{hr}$ with astrocytes. This neuroprotective effect of astrocytes was observed for concentrations of $\mathrm{H}_{2} \mathrm{O}_{2}(30-100 \mu \mathrm{M})$ that can be reached during reperfusion of the ischemic rat striatum (Hyslop et al., 1995), and it could be estimated that only one astrocyte has the capacity to significantly protect 20 neurons against the toxicity induced by the $30 \mathrm{~min}$ application of $100 \mu \mathrm{M}$ $\mathrm{H}_{2} \mathrm{O}_{2}$. As expected, this prominent astrocytic neuroprotection increased with the astrocytes/neurons ratio.

Several observations suggest that astrocytes protect neurons mainly by removing $\mathrm{H}_{2} \mathrm{O}_{2}$ from the external medium and not by releasing a possible neuroprotective compound. (1) The clearance capacity of astrocytes for $\mathrm{H}_{2} \mathrm{O}_{2}$ is particularly high because the rate of $\mathrm{H}_{2} \mathrm{O}_{2}$ disappearance from the astrocytic extracellular medium was sevenfold higher than from the neuronal incubating medium. (2) The attenuation of the toxic effects of the astrocyticconditioned media observed when astrocytes were incubatcd for increasing times with $100 \mu \mathrm{M} \mathrm{H}_{2} \mathrm{O}_{2}$ was in perfect correlation with the expected toxicity of the respective remaining concentrations of the oxidant. (3) Finally, the neurotoxic effects of various concentrations of $\mathrm{H}_{2} \mathrm{O}_{2}$ directly added to the striatal neurons were identical when they were tested using either a fresh unconditioned medium or astrocytic-conditioned media.

Catalase seems to be the main hydrogen peroxidase activity involved in the neuroprotective effect of astrocytes. Indeed, the inhibition of this enzyme, but not that of glutathione peroxidase, reduced the rate of $\mathrm{H}_{2} \mathrm{O}_{2}$ degradation by astrocytes. In addition, as estimated in cell homogenates, the activity of catalase was 4.5-fold higher in astrocytes than in neurons.

The size and shape of astrocytes could facilitate the catalaseinduced degradation of $\mathrm{H}_{2} \mathrm{O}_{2}$ by these cells. Indeed, in contrast to the neuronal cell bodies, which are small and rather spherical, 
astrocytes are much larger and spread out, forming a thin monolayer. Therefore, because of the surface/volume ratio, which is much higher for astrocytes than for neurons, $\mathrm{H}_{2} \mathrm{O}_{2}$ should more rapidly diffuse into astrocytes and thus reach a higher concentration in these cells than in neurons. Moreover, because $\mathrm{H}_{2} \mathrm{O}_{2}$ decomposition by catalase is a first-order reaclion, the rate of $\mathrm{H}_{2} \mathrm{O}_{2}$ disappearance is always proportional to the concentration of $\mathrm{H}_{2} \mathrm{O}_{2}$ in the cell (Aebi, 1984). Hence, the degradation of $\mathrm{H}_{2} \mathrm{O}_{2}$ by catalase should be further enhanced in astrocytes than in neurons. Finally, according to Harris and Rosenberg (1993), a physical sequestering of sensitive neuronal regions by astrocytes may facilitate the protection of neurons against glutamate toxicity. If such a cellular organization also occurs in our astrocytoneuronal cocultures, this should further reinforce the capacity of astrocytes to protect neurons.

As observed with catalase, the activity of glutathione peroxidase was also 4.5-fold higher in astrocytic than in neuronal homogenates. Nevertheless, the depletion of glutathione by the DEM pretreatment did not significantly alter the rate of $\mathrm{H}_{2} \mathrm{O}_{2}$ degradation by astrocytes. This apparent contradiction may result from the particular kinetic characteristics of glutathione peroxidase, which can be saturated by $\mathrm{H}_{2} \mathrm{O}_{2}$ but not by glutathione (Wendel, 1981). According to Makino et al. (1994), in fibroblasts, the activity of glutathione peroxidase is close to saturation at $100 \mu \mathrm{M} \mathrm{H} \mathrm{H}_{2} \mathrm{O}_{2}$, the concentration used in most of our experiments. Therefore, in our experimental conditions, the rate of $\mathrm{H}_{2} \mathrm{O}_{2}$ degradation by glutathione peroxidase should be more dependent on the concentration of glutathione than on that of $\mathrm{H}_{2} \mathrm{O}_{2}$. Interestingly, in our culture conditions, the content of glutathione in astrocytes was approximately twofold lower than that found in neurons. This could explain, at least partially, why the DEM-induced depletion of glutathione had a lower impact on the rate of $\mathrm{H}_{2} \mathrm{O}_{2}$ degradation by glutathione peroxidase in astrocytes than in neurons. Interestingly, when astrocytes were cultured in the neuronal medium for the last 6 $\mathrm{d}$, their content in glutathione reached the same range of that found in neurons, but the activities of catalase and glutathione peroxidase in these cells did not change. In this condition, the inhibitory effect of DEM on $\mathrm{H}_{2} \mathrm{O}_{2}$ degradation was substantial, but nevertheless, it remained lower than that of ATZ and thus catalase was still the main hydrogen peroxidase involved in the degradation of $\mathrm{H}_{2} \mathrm{O}_{2}$ by astrocytes. However, the latter observations suggest that modifications in the astrocyte environment can influence their glutathione content and therefore their protective effect against the $\mathrm{H}_{2} \mathrm{O}_{2}$-induced neurotoxicity.

In contrast to that found with astrocytes, glutathione peroxidase appears to be the main hydrogen peroxidase activity involved in the neuronal defense against $\mathrm{H}_{2} \mathrm{O}_{2}$ toxicity. Indeed, the inhibition of the activity of glutathione peroxidase, but not that of catalase, strongly aggravated the toxicity of $\mathrm{H}_{2} \mathrm{O}_{2}$, the oxidant being either added to the incubation medium or endogenously produced from menadione metabolism. Moreover, when neurons were incubated with menadione, $\mathrm{H}_{2} \mathrm{O}_{2}$ accumulated into the incubation medium only after the inhibition of glutathione peroxidase. Therefore, this enzymatic activity very likely ensures the protection of each neuron by reducing its intracellular concentration of $\mathrm{H}_{2} \mathrm{O}_{2}$. However, when compared with astrocytes, the much lower (sevenfold) capacity of neurons to clear $\mathrm{H}_{2} \mathrm{O}_{2}$ from the external medium suggests that the neuronal activity of glutathione peroxidase is too low to reduce to a large extent the extracellular concentration of added $\mathrm{H}_{2} \mathrm{O}_{2}$ and thus to protect neighboring neurons. This interpretation is also supported by additional results indicating that the
$\mathrm{H}_{2} \mathrm{O}_{2}$-induced neurotoxicity is not affected when the neuronal density is increased.

Because catalase follows first-order reaction kinetics, its marginal contribution to the neuronal protection against $\mathrm{H}_{2} \mathrm{O}_{2}$ could indicate that the intracellular concentration of $\mathrm{H}_{2} \mathrm{O}_{2}$ in neurons is maintained at a low level in the experimental conditions used. This could result from the high content of glutathione in neurons, which leads to a higher rate of $\mathrm{H}_{2} \mathrm{O}_{2}$ degradation by glutathione peroxidase. The respective subcellular locations of catalase and glutathione peroxidase could reinforce this process. Indeed, glutathione peroxidase is located in cytosol and in mitochondria (Flohé and Schlegel, 1971), whereas catalase is located predominantly in peroxisomes (Gaunt and DeDuve, 1976). Therefore, in neurons, the interaction of $\mathrm{H}_{2} \mathrm{O}_{2}$ with glutathione peroxidase and glutathione very likcly may intervene before the interaction with catalase. However, because of the flat shape of astrocytes, the consequences of this enzymatic subcellular compartmentalization should be more limited in these cells.

Despite the prominent protecting roles of catalase and glutathione peroxidase in astrocytes and in neurons, respectively, the simultaneous inhibition of these hydrogen peroxidase activities did not completely suppress the clearance of $\mathrm{H}_{2} \mathrm{O}_{2}$ in either cell type. Therefore, a nonenzymatic process, such as the Fenton reaction (Fenton, 1894), could also contribute to the disappearance of $\mathrm{H}_{2} \mathrm{O}_{2}$. Indeed, this reaction leads to the formation of hydroxyl radicals, which are probably responsible for the neurotoxic effects of $\mathrm{H}_{2} \mathrm{O}_{2}$ (Olanow, 1993).

In conclusion, our results demonstrate the protective role of astrocytes against $\mathrm{H}_{2} \mathrm{O}_{2}$ neurotoxicity. 'I'his provides an additional example of the neuroprotective properties of astrocytes. For instance, astrocytes have alrcady bccn shown to protect neurons against glutamate toxicity (Rosenberg and Aizenman, 1989). In both cases, the protecting effect of astrocytes is linked to their capacity to remove the compound responsible for the neuronal death from the extracellular space (Rosenberg, 1991; Dugan et al., 1995). As proposed by Harris and Rosenberg (1993) based on experiments performed with glutamate, the cellular organization should be of particular importance because astrocytes form a physical buffer allowing the interception of $\mathrm{H}_{2} \mathrm{O}_{2}$ before its interaction with neurons.

Because of their neuroprotective effect against $\mathrm{H}_{2} \mathrm{O}_{2}$, astrocytes could delay neurodegenerative processes such as Parkinson's disease and Alzheimer's disease, in which $\mathrm{H}_{2} \mathrm{O}_{2}$ has been, at least partially, demonstrated to be involved. Indeed, as proposed previously (Olanow, 1993), as a result of dopamine oxidation by monoamine oxidase, $\mathrm{H}_{2} \mathrm{O}_{2}$ could be generated within the nigrostriatal dopaminergic neurons whose degencration is rcsponsible mainly for Parkinson's disease. Astrocytes could also contribute to the development of Alzheimer's disease because $\mathrm{H}_{2} \mathrm{O}_{2}$ is an important intermediate in the $\beta$-amyloid protein-induced neurotoxicity (Behl et al., 1994).

\section{REFERENCES}

Aebi H (1984) Catalase in vitro. In: Methods in enzymology (Packer L, ed), pp 121-126. New York: Academic.

Behl C, Davis JB, Lesley R, Schubert D (1994) Hydrogen peroxide mediates amyloid $\beta$ protein toxicity. Cell 77:817-827.

Birman S, Cordier J, Glowinski J, Chneiweiss H (1989) Cyclic-AMP dependent protein kinase in mouse striatal neurones and astrocytes in primary culture: development, subcellular distribution and stimulation of endogenous phosphorylation. Neurochem Int 14:25-34.

Bradford MM (1976) A rapid and sensitive method for the quantitation of microgram quantities of protein utilizing the principle of protein dye binding. Anal Biochem 72:248-254. 
Buckman TD, Sutphin MS, Mitrovic B (1993) Oxidative stress in a clonal cell line of neuronal origin: effects of antioxidant enzyme modulation. J Neurochem 60:2046-2058.

Byler RM, Sherman NA, Wallner JS, Horwitz LD (1994) Hydrogen peroxide cytotoxicity in cultured cardiac myocytes is iron dependent. Am J Physiol 266:H121-H127.

Cantoni O, Guidarelli A, Sestili P, Mannello F, Gazzanelli G, Cattabeni F (1994) Hydrogen peroxide cytotoxicity under conditions of normal or reduced catalase activity in $\mathrm{H}_{2} \mathrm{O}_{2}$-sensitive and -resistant Chinese hamster ovary (CHO) cell variants. Toxicol Lett 73:193-199.

Clapp PA, Davies MI, French MS, Gilbert BC (1994) The bactericidal action of peroxides: an E.P.R. spin-trapping study. Free Radic Res Commun 21:147-167.

Coyle JT, Puttfarcken P (1993) Oxidative stress, glutamate, and ncurodegenerative disorders. Science 262:689-695.

Cross AR, Jones OTG (1991) Enzymic mechanisms of superoxide production. Biochim Biophys Acta 1057:281-298.

Denizot F, Lang R (1986) Rapid colorimetric assay for cell growth and survival. Modifications to the tetrazolium dye procedure giving improved sensitivity and reliability. J Immunol Methods 89:271-277.

Dugan LL, Bruno VMG, Amagasu SM, Giffard RG (1995) Glia modulate the response of murine cortical neurons to excitotoxicity: glia exacerbate AMPA neurotoxicity. J Neurosci 15:4545-4555.

El Etr M, Cordier J, Glowinski J, Premont J (1989) A neuro-glial cooperativity is required for the potentiation by 2-chloroadenosine of the muscarinic-sensitive phospholipase $\mathrm{C}$ in the striatum. J Neurosci 9:1473-1480.

Eng LF (1985) Glial fibrillary acid protcin (GFAP): the major protein of glial intermediate filaments in differentiated astrocytes. J Neuroimmunol 8:203-214.

Fenton HJH (1894) Oxidation of tartaric acid in the presence of iron. J Chem Soc (Lond) 65:899-903.

Flohé L, Günzler WA (1984) Assays of glutathione peroxidase. In: Methods in enzymology (Packer L, ed), pp 114-121. New York: Academic.

Flohé L, Schlegel W (1971) Glutathione peroxidase. IV. Intracellular distribution of the glutathione peroxidase system in the rat liver. HoppeSeyler's Z Physiol Chem 352:1401-1410.

Gaunt GL, DeDuve C (1976) Subcellular distribution of D-amino acid oxidase and catalase in rat brain. $\mathrm{J}$ Neurochem 26:749-759.

Gilman SC, Bonner MJ, Pellmar TC (1994) Free radicals enhance basal release of $D-\left[{ }^{3} \mathrm{H}\right]$ aspartate from cerebral cortical synaptosomes. J Neurochem 62:1757-1763.

Glenner GG (1988) Alzheimer's disease: its proteins and genes. Cell 52:307-308.

Haber F, Weiss J (1934) The catalytic decomposition of hydrogen peroxide by iron salts. Proc R Soc Lond Ser A 147:332-351.

Halliwell B (1992) Reactive oxygen species and the central nervous system. J Neurochem 59:1609-1623.

Harris KM, Rosenberg PA (1993) Localization of synapses in rat cortical cultures. Neuroscience 53:495-508.

Hyslop PA, Zhang Z, Pearson DV, Phebus LA (1995) Measurement of striatal $\mathrm{H}_{2} \mathrm{O}_{2}$ by microdialysis following global forebrain ischemia and reperfusion in the rat: correlation with the cytotoxic potential of $\mathrm{H}_{2} \mathrm{O}_{2}$ in vitro. Brain Res 671:181-186.

Kim YS, Kim SU (1991) Oligodendroglial cell death induced by oxygen radicals and its protection by catalase. J Neurosci Res 29:100-106.
Lafon-Cazal M, Pietri S, Culcasi M, Bockaert J (1993) NMDAdependent superoxide production and neurotoxicity. Nature 364 535-537.

Loo DT, Copani A, Pike CJ, Whittemore ER, Walencewicz AJ, Cotman CW (1993) Apoptosis is induced by $\beta$-amyloid in cultured nervous system neurons. Proc Natl Acad Sci USA 90:7951-7955.

Makar TK, Nedergaard M, Preuss A, Gelbard AS, Perumal AS, Cooper A.I (1994) Vitamin E, ascorbate, glutathione, glutathione disulfide, and enzymes of glutathione metabolism in cultures of chick astrocytes and neurones: evidence that astrocytes play an important role in antioxidative processes in the brain. J Neurochem 62:45-53.

Makino N, Mochizuki Y, Bannai S, Sugita Y (1994) Kinetic studies on the removal of extracellular hydrogen peroxide by cultured fibroblasts. J Biol Chem 269:1020-1025.

Marin P, Maus M, Desagher S, Glowinski J, Prémont J (1994) Nicotine protects cultured striatal neurones against $N$-methyl-D-aspartate receptor-mediated neurotoxicity. NeuroReport 5:1977-1980.

Matus A, Bernhardt R, Hugh-Jones T (1981) High molecular weight microtubule-associated proteins are preferentially associated with dendritic microtubules in brain. Proc Natl Acad Sci USA 78:3010-3014.

Meister A (1988) Glutathione metabolism and its selective modification. J Biol Chem 263:17205-17208.

Olanow CW (1993) A radical hypothesis for neurodegeneration. Trends Neurosci 16:439-444

Plummer JL, Smith BR, Sies H, Bend JK (1981) Chemical depletion of glutathione in vivo. In: Methods in enzymology (Colowick SP, Kaplan NO, eds), pp 50-59. New York: Academic.

Raps SP, Lai JCK, Hertz L, Cooper AJL (1989) Glutathione is present in high concentration in cultured astrocytes but not in cultured neurons. Brain Res 493:398-401.

Rosenberg PA (1991) Accumulation of extracellular glutamate and neuronal death in astrocyte-poor cortical cultures exposed to glutamine. Glia 4:91-100.

Rosenberg PA, Aizenman E (1989) Hundred-fold increase in neuronal vulnerability to glutamate toxicity in astrocyte-poor cultures of rat cerebral cortex. Neurosci Lett 103:162-168.

Sagara J, Miura K, Bannai S (1993) Maintenance of neuronal glutathione by glial cells. J Neurochem 61:1672-1676.

Schonbaum GR, Chance B (1976) Catalase. In: The enzymes (Boyer PD, ed), pp 363-408. New York: Academic.

Théry C, Chamak B, Mallat M (1991) Cytotoxic effect of brain macrophages on developing neurons. Eur J Neurosci 3:1155-1164.

Thor H, Smith MT, Hartzell P, Bellomo G, Jewell SA, Orrenius S (1982) The metabolism of menadione (2-methyl-1,4-naphtoquinone) by isolated hepatocytes. J Biol Chem 257:12419-12425.

Tietze F (1969) Enzymic method for quantitative determination of nanogram amounts of total and oxidized glutathione: applications to mammalian blood and other tissues. Anal Biochem 27:502-522.

Wendel A (1981) Glutathione peroxidase. In: Methods in enzymology (Colowick SP, Kaplan NO, eds), pp 325-333. New York: Academic.

White EJ, Clark JB (1988) Menadione-treated synaptosomes as a model for post-ischaemic neuronal damage. Biochem J 253:425-433.

Whittemore ER, Loo DT, Cotman CW (1994) Exposure to hydrogen peroxide induces cell death via apoptosis in cultured rat cortical neurons. NeuroReport 5:1485-1488. 